MAR JIMENO-BULNES*

\title{
BREXIT AND THE FUTURE OF EUROPEAN CRIMINAL LAW - A SPANISH PERSPECTIVE
}

\author{
All of us share interests and values in common, values we want to see \\ projected around the world. ${ }^{1}$
}

\begin{abstract}
The UK public took a momentous decision when they voted to leave the EU in a referendum on 23 June 2016. As is well known, the UK has, since the entry into force of the Treaty of Lisbon on 1 December 2009, occupied a special position in relation to the Area of Freedom, Security and Justice (ELSJ, Title V TFEU). The Treaty introduced fundamental changes to the field of EU Criminal Law, from which the UK had been sheltered through the opt in/opt out clauses as well as the 'emergency brakes' solution. This singular arrangement for the UK after having signed the Treaty of Lisbon might, to some extent, have foreshadowed the present situation of Brexit, the consequences of which for EU Criminal Law are foreseen in this paper from a Spanish perspective. It presents an analysis of what the alternatives to the current relationships between Spain and UK could be in the future outside the EU framework, nevertheless while seeking to benefit from the improvements previously established through European institutions and instruments. In this context, three different areas are addressed: the natural framework through the relations that will inevitably exist with European agencies and institutions; the procedural framework in the area of judicial recognition through the application of the principle of mutual recognition; and, the framework in relation to procedural rights through the application of the principle of the approximation of laws. Finally, some brief remarks outline conclusions on a situation that is still unfolding.
\end{abstract}

\section{INTRODUCTION}

A majority of the United Kingdom ("UK") Supreme Court ${ }^{2}$ magistrates has ruled that the UK Parliament should vote on the European Union ("EU") Act $2011^{3}$ before the

\footnotetext{
* Full Professor at the University of Burgos (Spain) and non-practicing member of the Burgos Bar Association. Correspondence e-mail: Mjimeno@ubu.es. The financial support of the Spanish Ministry of Economy and the European Commission is gratefully acknowledged (Research Projects 'A step forward in the consolidation of the European judicial area and its practical application in Spain: from the perspective of civil and criminal procedures', DER2015-71418-P and Best practices for EUROpean COORDination on investigative measures and evidence gathering, EUROCOORD, JUST-2015-JCOOAG, 723198). Also, my special thanks to Professors Kai Ambos and Stefanie Bock for their invitation at that time to join the present workshop; thanks also to my aunt Crys Bulnes for sending me press news on Brexit from UK. Last and not least, thanks to Antony Ross Price for revising the English language version of this article.

1 T May, Brexit speech, Lancaster House, 17 January 2017, available at http://www.telegraph.co.uk/news/2017/01/17/theresa-mays-brexit-speech-full/ (last visited: 31 March 2017).
} 
government can invoke Article 50 Treaty on European Union ("TEU") and formally initiate Brexit through a Great Repeal Bill. ${ }^{4}$ This situation means that an Act of Parliament is necessary in order to abrogate the 1972 European Communities Act, although the UK Supreme Court considered the consent of the devolved assemblies in Scotland, Northern Ireland and Wales unnecessary. The 'British exit' is looming and the world is watching each step taken by the UK in relation to the devolutionary aspects of Brexit according to the British Constitution, ${ }^{5}$ which could perhaps serve as a model in the future for some other Member States.

It is no longer a matter of complaining about Brexit ${ }^{6}$ or justifying the particularly reluctant attitude of the UK towards unreserved participation in the EU and its probable historical reasons. ${ }^{7}$ What it is clear throughout the EU is that Brexit will have significant fallout on the one-to-one relationships between the UK, the EU and all of its Member States, in so far as the UK will no longer be subject to EU Law. Future relations between the UK and Spain will be discussed, against the backdrop of EU Criminal Law. Concern is in fact growing in Spain over the consequences of Brexit, ${ }^{8}$ logically enough in view of the evident uncertainty over the post-Brexit future of the

\footnotetext{
${ }^{2}$ Eight of the eleven Supreme Court magistrates voted in favour. A press summary and the full judgment are available at https://www.supremecourt.uk/news/article-50-brexit-appeal.html Also, extensively reported in the press; see for example https:/www.theguardian.com/politics/2017/jan/24/supreme-courtbrexit-ruling-parliament-vote-article-50 (last visited: 31 March 2017).

${ }^{3}$ Enacted on 19 July 2011, available at http://www.legislation.gov.uk/ukpga/2011/12 (last visited: 31 March 2017).

4 Brief information available at https://www.instituteforgovernment.org.uk/brexit/brexit-brief-greatrepeal-bill (last visited: 31 March 2017).

${ }^{5}$ See especially S Douglas-Scott, 'Brexit, Article 50 and the contested British Constitution' (2016) 79 The Modern Law Review 1019; also, R Kaiser, 'Auf dem Weg zum "Brexit" - die Europäische Union im britischen Verfassungsrecht' (2016) 51 Europarecht, 593.

${ }^{6}$ See for example P Craig, 'Brexit: a drama in six acts' (2016) 41 European Law Review 447 as well as O Blin, 'Did Brexit break it?' [2016] Recueil Dalloz 1440-1441.

${ }^{7}$ See in Spain R Gosalbo Bono, ‘Brexit o Bremain?’ [2016] Revista General de Derecho Europeo, available at http://www.iustel.com, 6 and ff, in relation to what the author calls 'the British problem'. Also, in general, A Thiele, 'Der Austritt aus der EU - Hintergründe und rechtliche Rahmenbedingungen eines "Brexit"' (2016) 51 Europarecht 281.

${ }^{8}$ Cf. C Escobar Hernández, 'Brexit: algunas reflexiones desde el Derecho Internacional' (2016) 68 Revista española de Derecho Internacional 19; also A Mangas Martín, 'La retirada del Reino Unido de la Unión Europea' (2016) 19 Foro, Nueva Época 29. In the context of Criminal Law see especially P Solar Calvo, 'Consecuencias penales del Brexit' (2016) 42 Revista Aranzadi Unión Europea 113 as well as G Quintero Olivares, 'Sobre posibiles consecuencias penales del Brexit' (2017) 45 Revista Aranzadi de Derecho y proceso penal 165.
} 
EU. ${ }^{9}$ This situation is unprecedented, as up until now, countries only have sought entry to the EU.

As mentioned above,${ }^{10}$ the special terms of the UK's accession to the Treaty of Lisbon signed on 13 December 2007, ${ }^{11}$ which entered into force on 1 December 2009, in some ways foreshadowed Brexit. It leaves the UK upholding a singular position in the EU scenario, ${ }^{12}$ especially in relation to the area of freedom, security and justice (Title V, Arts. 67-89 TFEU, henceforth AFSJ). ${ }^{13}$ In fact, the Treaty of Lisbon generally provides a 'more European'14 approach establishing some improvements in the area of AFSJ, seen until then as the "wicked stepmother of the EU system';" 15 basically, these improvements are: a) suppression of the earlier structure of the three pillars and the extension of the 'community method'; b) unification of the legal sources of EU Law (rulings, directives and decisions); c) the attachment of a binding effect to the European Charter of Fundamental Rights ${ }^{16}$ and the extension of ECJ jurisdiction ${ }^{17}$ throughout the

\footnotetext{
${ }^{9}$ See J Snell, 'Brexit: the age of uncertainty' (2016) 41 European Law Review 445; also F Schorkopf, 'Three nearly-certain conclusions we can draw from uncertainty' (2016) 17 German Law Journal 95. Specifically in Spain A Mangas Marín, 'Postbrexit: una Europa confusa, entre el desánimo y la incertidumbre' (2016) 20 Revista de Derecho Comunitario Europeo 427. See generally K Ambos and S Bock, 'Brexit and the European Criminal Justice System - An Introduction', supra in this issue, 3.4.
}

${ }^{10}$ I completely agree with V. Mitsilegas, 'The uneasy relationship between the UK and European Criminal Law: from opt-outs to Brexit?' (2016) 63 Criminal Law Review 517.

${ }^{11}$ OJ EU C 115 of 9 May 2008, 1 and OJ EU C 83 of 30 March 2010,1. In relation with EU Criminal Law see specifically M Jimeno Bulnes, 'La conclusión del Tratado de Lisboa: avances y concesiones en materia de cooperación judicial penal' [2008] Diario La Ley, 30 September, no 7023, 1.

${ }^{12}$ See at the time references on 'exceptionalism' and 'differentiation' in ASFJ by S Carrera and F Geyer, 'The Reform Treaty and Justice and Home Affairs: implications for the common Area of Freedom, Security and Justice', in E Guild and F Geyer (eds) Security versus Justice? Police and judicial cooperation in the European Union (Aldershot and Burlington, Ashgate, 2008) 289 at 303.

13 See, generally, M Fletcher, 'EU criminal justice beyond Lisbon', in C Eckes and T Konstantinides (eds), Crime within the Area of Freedom, Security and Justice. A European Public Prosecutor (Cambridge, Cambridge University Press, 2011) 10 as well as E Herlin Karnell, 'EU competence in Criminal Law after Lisbon', in A Biondi, P Eeckhout and S Ripley (eds) EU Law after Lisbon (Oxford, Oxford University Press, 2012) 331.

${ }^{14}$ Or the idea of an 'ever closer Union'; see extensively A Allué Buiza (ed.), 'La retirada de Gran Bretaña de la Unión Europea ("Brexit”)' [2016] Revista de Estudios Europeos 1.

15 In the words of S Peers, 'Justice and Home Affairs Law since the Treaty of Lisbon: a fairy-tale ending?', in D Acosta Arcadarazo and C C Murphy (eds) EU Security and Justice Law after Lisbon and Stockholm (Oxford and Oregon, Hart Publishing, 2014) 17 at 17.

${ }^{16}$ Signed on 7 December 2000, OJ EC C 364 of 18 December 2000, 1 and confirmed on 12 December 2007, OJ EU C 303 of 14 December 2007, 1. Note the special position that the UK jointly adopted with Poland in Protocol No 30, OJ C EU 115 of 9 March 2008, 313.

${ }^{17}$ Following the Treaty of Lisbon, the Court of Justice of the EU (CJEU), but still commonly referred to as the European Court of Justice (ECJ). 
area of freedom, security and justice. This last matter represents a key point for the British Government in its arguments for leaving Europe. ${ }^{18}$

The UK and Ireland both signed Protocols 21 and $36^{19}$ accompanying the Treaty of Lisbon, stressing their particular positions in relation to the AFSJ through the opt-in and opt-out clauses. ${ }^{20}$ Besides, the UK has benefited from transitional measures for over five years, thereby circumventing the jurisdiction of the ECJ in relation to the AFSJ; this period finished on 1 December 2014, the date on which the UK communicated a list of acts into which it wished to 'opt back' ${ }^{21}$. The whole situation created a sort of 'justice à la carte ${ }^{22}$ of benefit to the UK; presaging once again what is now a very real debate over Brexit, that is, the potential loss of national sovereignty including the independence of the British criminal justice system. ${ }^{23}$

In this context, the specific consequences of Brexit in Spain will be analysed in relation to EU Criminal Law policy. The present inquiry will address three different areas: the institutional area, judicial cooperation in application of the principle of mutual recognition, and the area of procedural rights in application of the principle of

${ }^{18}$ See E Herlin-Karnell, 'Constitutional principles in the Area of Freedom, Security and Justice' in D Acosta Arcadarazo and C C Murphy (eds) EU Security and Justice Law after Lisbon and Stockholm (Oxford and Oregon, Hart Publishing, 2014) 38 at 52.

${ }^{19}$ Protocol 21 on the Position of the UK and Ireland in Respect of the Area of Freedom, Security and Justice, consolidated version in OJ EU C 202 of 7 June 2016, 295; Protocol 36 on Transitional Provisions, OJ EU C 115 of 8 May 2008, 322.

${ }^{20}$ See for example E Baker, 'The United Kingdom and its Protocol 36 Opt-Out: is police judicial cooperation in criminal matters within the EU losing momentum' (2013) 21 European Journal of Crime, Criminal Law and Criminal Justice 237 and H. Labayle, 'Within you, without you: 1'opt out britannique en matière d'entraide répressive' (2013) 23 Europe: actualité du droit communautaire 6. As said, a 'result' of the provision of opt in/out clauses is that the 'degree of cooperative participation of the EU Member States in the AFSJ has diminished'; see J de Zwaan, 'The new governance of Justice and Home Affairs: towards further supranationalism' in S Wolff, F A N J Goudappel and J de Zwaan (eds) Freedom, security and justice after Lisbon and Stockholm (The Hague, T.M.C. Asser Press, 2011) 7 at 24.

${ }^{21}$ Commission Decision 2014/858/EU of 1 December 2014 on the Notification by the United Kingdom of Great Britain and Northern Ireland of its Wish to Participate in Acts of the Union in the Field of Police Cooperation and Judicial Cooperation in Criminal Matters Adopted Before the Entry Into Force of the Treaty of Lisbon and Which are not Part of the Schengen Acquis, OJ EU L 345 of 1 December 2014, 6. On the same date a list of Union acts adopted after the entry into force of the Treaty of Lisbon was published, the application of which the UK decided either to opt into or opt out of; see OJ EU C 430 of 1 December 2014, 17 and 23.

${ }^{22}$ See V Mitsilegas, EU Criminal Law after Lisbon. Rights, trust and the transformation of Justice in Europe (Oxford, and Portland, Hart Publishing, 2016) 44. As has been stated, the UK has been "the major beneficiary of the EU's variable geometry"; see N Walker, 'The European fallout' (2016) 17 German Law Journal 125 at 126. Also in general on this 'variable geometry' A Klip, European Criminal Law. An integrative approach (3rd ed., Antwerpen, Intersentia, 2016) 61

${ }^{23}$ See J Ouwerkerk, 'Criminal justice beyond national sovereignty. An alternative perspective of the Europeanization of Criminal Law' (2015) 23 European Journal of Crime, Criminal Law and Criminal Justice 11 at 13 . 
approximation of law. It is time for Spain to 'reinvent' its relationship with the UK outside the EU framework.

\section{INSTITUTIONS AND AGENCIES}

As is well known, at the moment the Proposal for a Council Regulation on the establishment of the European Public Prosecutor's Office ${ }^{24}$ (“EPPO”) is still under negotiation. A minimum consolidated text still under negotiation appears to have been adopted during the Slovak Presidency of the EU Council ${ }^{25}$ as result of the Justice and Home Affairs meeting held on 8-9 December 2016 in Brussels. ${ }^{26}$ The UK has opted out of this initiative, ${ }^{27}$ although it is very active in other EU bodies and agencies ${ }^{28}$ such as Eurojust and Europol. ${ }^{29}$ In contrast, Spain is very supportive of the EPPO proposal and

\footnotetext{
${ }^{24}$ Brussels, 17.7.2013, COM(2013) 534 final. See specific comments by M Caianiello, 'The Proposal for a Regulation on the establishment of a European Public Prosecutor's Office: everything changes or nothing changes?' (2013) 21 European Journal of Crime, Criminal Law and Criminal Justice 115 and L Bachmaier Winter, 'The potential contribution of a European Public Prosecutor in light of the Proposal for a Regulation of 17 July 2013' (2015) 23 European Journal of Crime, Criminal Law and Criminal Justice 121. In Spain for example M L Escalada López, 'Los instrumentos de cooperación judicial europea: hacia una futura fiscalía europea' (2014) 18 Revista de Derecho Comunitario Europeo 89 at 118 as well as, in general, M A Pérez Marín, 'La futura fiscalía europea', in M Jimeno Bulnes (ed), Aproximación legislativa versus reconocimiento mutuo en el desarrollo del espacio judicial europeo: una perspectiva multidiciplinar (Barcelona Bosch, 2016) 265.

${ }^{25}$ The most recent public document available still at the time of writing this article was provided by the Presidency to Council on 31 January 2017, n. 5766/17, LIMITE, EPPO 5, EUROJUST 14, CATS 10, FIN 52, COPEN 21, GAF 6, CSC 30 available at http://www.consilium.europa.eu/register/en/content/int/ (last visited: 6 April 2017).

26 3508th Council meeting, document no 15391/16, PRESSE 67, PR CO 66, available at www.consilium.europa.eu/en/meetings/jha/.../st15391_en16 pdf (last visited: 31 March 2017). By contrast, last JHA meeting on 27 and 28 March 2017 did not include any debate on the topic; see press communication available at www.consilium.europa.eu/en/meetings/jha/.../st15391 en 16 pdf (last visited: 31 March 2017).

${ }^{27}$ According to s. 6 (5) (c) EU Act 2011 an Act by the UK Parliament and a referendum are required.

${ }^{28}$ The main agencies in the field of judicial cooperation in criminal matters are the liaison magistrates, the European Judicial Network and Eurojust. See M L Escalada López, 'Los instrumentos de cooperación judicial europea: hacia una futura fiscalía europea', above n 24; also id, 'Instrumentos orgánicos: en especial, redes judiciales europea en materia civil, mercantil y penal', in M Jimeno Bulnes (ed) Nuevas aportaciones al espacio de libertad, seguridad y justicia. Hacia un Derecho Procesal europeo de naturaleza civil y penal (Granada, Comares, 2014) 47-81 and 'Instrumentos orgánicos de cooperación judicial: magistrados de enlace, red judicial europea y Eurojust' in M. Jimeno Bulnes (ed) La cooperación judicial civil y penal en el ámbito de la Unión Europea: instrumentos procesales (Barcelona: Bosch, 2007) 95. Extensively N Alonso Moreda, La dimensión institucional de la cooperación judicial en materia penal en la Unión Europea: magistrados de enlace, Red Judicial Europea y Eurojust (San Sebastián, Universidad del País Vasco, 2010).

${ }^{29}$ It should be remembered that two of four presidents of Eurojust were British, including the inaugural one (Mike Kennedy) and the current director of Europol (Rob Wainwright) is also from the UK. See information provided on the Interpol website at https://www.europol.europa.eu/director-of-europol (last visited: 31 March 2017).
} 
numerous seminars as well as publications have been held on the matter over recent years. $^{30}$

According to the earlier opt-back-in clause by the Commission Decision 2014/858/EU of 1 December 2014, ${ }^{31}$ among all the measures listed, several concerning the participation of the UK in EU criminal justice bodies and agencies are also included such as: (7) Council Decision 2002/187/JHA of 28 February 2002 to set up Eurojust with a View to Reinforcing the Fight against Serious Crime, ${ }^{32}$ (19) Council Framework Decision 2008/976/JHA of 16 December 2008 on the European Judicial Network ("EJN") ${ }^{33}$ and (24) Council Decision 2009/371/JHA of 6 April 2009 establishing the European Police Office (Europol). ${ }^{34}$ In contrast, the UK unfortunately decided at the time $^{35}$ to opt-out of Joint Action 96/277/JHA of 22 April 1996 Concerning a Framework for the Exchange of Liaison Magistrates to Improve Judicial Cooperation between the EU Member States. ${ }^{36}$

This fact is relevant for Spain, because it has always exchanged liaison magistrates with the UK in the past, as an essential mechanism for procedures such as the issuance and enforcement of European Arrest Warrants ("EAW") in line with judicial practice. ${ }^{37}$

\footnotetext{
${ }^{30}$ See for example the book prepared at the time by the Spanish General Prosecutor's Office after the conference held on 24-25 January 2008, J A Espina Ramos and I Vicente Carbajosa (eds), The future European Public Prosecutor's Office (Madrid, Center of Legal Studies of the Ministry of Justice, 2009).

${ }^{31}$ Supra note 21. See Mitsilegas, EU Criminal Law after Lisbon, above $\mathrm{n} 22$ at 47.

${ }^{32}$ OJ EC L 63 of 6 March 2002, 1, amended by Council FD 2003/659/JHA of 18 June 2003, OJ EU L 245 of 29 September 2003, 44 and Council FD 2009/426/JHA of 16 December 2008, OJ EU L 138 of 4 June 2009,14 . See also the information available from the official website $h \mathrm{ttp}: / /$ www.eurojust.europa.eu In relation with such evolution and powers of Eurojust see Mitsilegas, EU Criminal Law after Lisbon, above n 22 at 94-103; also specifically J Vlastnik, 'Eurojust - A cornerstone of the Federal Criminal Justice system in the EU?', in E Guild and F Geyer (eds), Security versus Justice? Police and judicial cooperation in the European Union (Aldershot and Burlington, Ashgate, 2008) 35.

${ }^{33}$ OJ EU L 348 of 24 December 2008, 130; see also the information available from the Eurojust website https://www.ejn-crimjust.europa.eu/ejn . In Spain, A Galgo Peco, 'La Red Judicial Europea y los nuevos instrumentos de agilización y coordinación' [2002] Estudios Jurídicos. Ministerio Fiscal 445.

${ }^{34}$ OJ EU L 121 of 15 May 2009, 37; also information available from its website, supra note 26. For a comparative view with Interpol, see for example M Richardot, 'Interpol, Europol' [2002] Pouvoir. Revue française d'études constitutionnelles et politiques 77.

${ }^{35}$ See list of acts adopted before the entry into force of the Lisbon Treaty in the field of police cooperation and judicial cooperation which ceased to apply to the United Kingdom as from 1 December 2014 pursuant to Article 10 (4) Protocol 36.

${ }^{36}$ OJ EC L 105 of 27 April 1996, 1. For example in Spain L Rodriguez Sol, 'Los magistrados de enlace' (2000) Diario la Ley, 14 June, no 5075, http://diariolaley.laley.net

${ }^{37}$ At the time there have even been bilateral meetings and seminars with the attendance of British and Spanish practitioners, British liaison magistrates included, e.g., Bilateral seminar between UK and Spain on EAW implementation held in Madrid (General Prosecutor's Office) on 21-22 February 2008 with the attendance of Dominic Barre, UK liaison magistrate, among other participants. I am grateful for the information provided by the Public Prosecutor Francisco Jiménez-Villarejo, at present a Spanish national
} 
Spain also maintains liaison magistrates in France and Italy, countries with which Spain, as with the UK, has a constant flow of 'rogatory letters' (comisiones rogatorias) in request for judicial assistance; at the moment the appropriate judicial authorities are Benedict Leonard, the UK liaison magistrate, and Miguel Carmona, the Spanish liaison magistrate. But Spain also exchanges liaison magistrates with non-EU countries such as Morocco $^{38}$ in so far as this possibility is recognized specifically in the Spanish Law $16 / 2006$, on 26 May, by which the Statute of the National Member of Eurojust is regulated and the relations with this organ of the EU; in concrete, the possibility is foreseen of establishing positions for liaison magistrates according to 'EU Law, international treaties and reciprocity, ${ }^{39}$ As for other countries, this option will also apply to the UK when and if it becomes a third state outside of the EU.

The example provided by Eurojust is a further argument in favour of such a position in this context. In fact, the College of Eurojust at present includes ${ }^{40}$ Deputy National Members and Assistants to National Members together with National Members, and the institution of Liaison Magistrates; in concrete, liaison magistrates from the following three countries: Norway (Petter Sodal), United States (Michael Olmsted), and Switzerland (Maria Schnebli). ${ }^{41}$ The probable reasoning behind this maintenance of liaison magistrates with these third states is the frequency of, for example and among other tasks, ${ }^{42}$ joint investigations and the solution of jurisdictional conflicts between one

member of Eurojust; see http://www.eurojust.europa.eu/about/structure/college/Pages/nationalmembers.aspx (last visited: 31 March 2017).

38 At the moment, Luis Francisco Jorge de Mesa. See list of liaison magistrates for Spain with their electronic addresses in the 'Guide on best practices for the Spanish judicial authorities to seek the assistance of liaison magistrates, the European judicial network, Eurojust and Iberred' available from the website of the Spanish General Prosecutor's Office https://www.fiscal.es, 3.

${ }^{39}$ Additional first provision; see Spanish Official Journal (Boletín Oficial del Estado, henceforth BOE) no 126, 27.5.2006, consolidated version available at https://www.boe.es/buscar/act.php?id=BOE-A-20069294 (last visited: 31 March 2017).

40 New Art. 2 (7) Council Decision 2002/187/JHA amended by Art. 1 (1) Council Decision 2009/426/JHA. See comments by C Tirado Robles, 'El refuerzo de la cooperación judicial penal en la Unión Europea. Comentario a la Decisión del Consejo 2009/426/JHA, de 16 de diciembre de 2008' [2010] Revista General de Derecho Europeo 10.

41 Information available at http://www.eurojust.europa.eu/about/structure/college/Pages/liaisonmagistrates.aspx (last visited: 31 March 2017).

42 See Art. 7 Council Decision 2002/187/JHA amended by Art. 1 (6) Council Decision 2009/426/JHA. Also useful on this topic are the annual reports prepared by Eurojust available at http://www.eurojust.europa.eu/doclibrary/corporate/Pages/annual-reports.aspx (last visited: 31 March 2017); according to the 2015 Annual Report (p. 48), "Eurojust provided assistance in 298 involving third States ... Of the 63 States, Switzerland (103) was the most frequently involved third State, followed by the USA (36), Norway (34) and Serbia (31)". Precisely the first third States have liaison magistrates as indicated. 
of them and any Member States at EU level. ${ }^{43}$ Of course, a future liaison magistrate from the UK will also be envisaged when it assumes its status as a third state.

\section{MUTUAL RECOGNITION INSTRUMENTS: THE EUROPEAN ARREST WARRANT IN PRACTICE}

It should be pointed out that the UK has been always favourable towards the adoption of mutual recognition measures on behalf of judicial cooperation in criminal matters and police cooperation. Hardly surprisingly, the UK also participates in the adoption of the Directive 2104/241/EU of the European Parliament and of the Council of 3 April 2014 regarding the European Investigation Order in Criminal Matters ("EIO"), ${ }^{44}$ the implementation of which must take place by 22 May 2017 according to Article 36 (1). The last-mentioned order replaces the previous Council Framework Decision 2008/978/JHA of 18 December 2008 on the European Evidence Warrant for the purpose of Obtaining Objects, Documents and Data for Use in Proceedings in Criminal Matters. ${ }^{45}$ In fact, the UK had already announced its agreement to that change and its wish to accept the EIO, ${ }^{46}$ but the proximity of Brexit means that its transposition and practical application is more than unlikely. ${ }^{47}$

\footnotetext{
${ }^{43}$ Practice by Eurojust indicates its involvement in conflicts of jurisdiction not only between Member States but also with third states; see some cases with third states in prior Eurojust Annual Report 2015, 50. Also comments in relation with some examples on the topic of conflicts of jurisdiction by $\mathrm{N}$ Alonso Moreda, 'Eurojust, a la vanguardia de la cooperación judicial en materia penal en la Unión Europea' (2012) 16 Revista de Derecho Comunitario Europeo, 119 at 135. See also, generally, in relation with such liaison magistrates from third states N. Alonso Matera, La dimension institucional de la cooperación judicial en material penal en la Unión Europea: magistrados de enlace, Red Judicial europea y Eurojust (San Sebatián, Servicio Editorial UPV) 234.

44 OJ EU L 130 of 1 May 2014, 1. See M Jimeno Bulnes, 'Orden europea de investigación en materia penal', in M Jimeno Bulnes (ed), Aproximación legislativa versus reconocimiento mutuo en el desarrollo del espacio judicial europeo: una perspectiva multidiciplinar (Barcelona Bosch, 2016) 151 with various relevant references of interest. Also basically L Bachmaier Winter, 'Transnational evidence. Towards the transposition of Directive 2014/241/EU regarding the European Investigation Order in criminal matters' (2015) 9 Eucrim 47; at the time, criticism by A Mangiaracina, 'A new and controversial scenario in the gathering of evidence at the European level: the Proposal for a Directive on the European Investigation Order' (2014) 14 Utrecht Law Review 113.

45 OJ EU L 350 of 30 December 2008, 72-92. See Art. 34 (2) Directive 2014/241/EU; also according to further Art. 1 Regulation 2016/95/EU of the European Parliament and of the Council of 20 January 2016 Repealing Certain Acts in the Field of Police Cooperation and Judicial Cooperation in Criminal Matters, OJ EU L 26 of 2 February 2016, 9.

46 See list of acts adopted before the entry into force of the Lisbon Treaty in the field of police cooperation and judicial cooperation which have been amended by an act applicable to the United Kingdom adopted after the entry into force of the Lisbon Treaty and which therefore remain applicable to the United Kingdom as amended or replaced, 2014/C 430/04, above num. 21.

${ }^{47}$ See Mitsilegas, The uneasy relationship between the UK and European Criminal Law: from opt-outs to Brexit?', above n 10 at 530, regretting its abandonment.
} 
It must be recalled that the idea of the mutual recognition of judicial decisions as the 'cornerstone of judicial cooperation in both civil and criminal matters within the Union' ${ }^{48}$ established as a principle at the Tampere European Council (1999) was the fruit of a British presidency. The Home Secretary to the government of Tony Blair, Jack Straw launched ${ }^{49}$ the new project at the Cardiff European Council (1998). ${ }^{50}$ The UK placed mutual recognition on the agenda as an alternative to legislative harmonization, the common minimum standards of which are to date unavoidable in EU territory. ${ }^{51}$ The harmonization process threatened to compromise the continuance of the Common Law system in EU Law as the majority of the then 15 Member States follow the Civil Law system. ${ }^{52}$ The UK revolutionized the field of European judicial cooperation with this project, drawn from the well-known judgment of Cassis de Dijon ${ }^{53}$. The application of the principle of mutual recognition in the EU judicial area opened the door to a sort of free circulation of judicial decisions, which became the fifth community freedom or, for others, the roaming ${ }^{54}$ of judicial cooperation in criminal matters.

UK interest in instruments of mutual recognition is evident in its decisions to back several Framework Decisions relating to judicial cooperation in criminal matters, in

\footnotetext{
${ }^{48}$ Conclusion no 33; see Tampere European Council 15 and 16 October 1999, Presidency Conclusions, available at http://www.europarl.europa.eu/summits/tam en.htm (last visited: 31 March 2017); cf. also K Ambos and S Bock, 'Brexit and the European Criminal Justice System - An Introduction', supra in this issue, 3.4.

${ }^{49}$ It appears that its origin was at a lunch on March 1998, as recalled by H G Nilsson, 'Mutual trust or mutual distrust', in G De Kerchove and A Weyembergh (eds), La confiance mutuelle dans l'espace pénal européen/ Mutual trust in the European Criminal Area (Brussels, Editions de l'Université Libre de Bruxelles, 2005) 29 at 29.

${ }^{50}$ In fact Conclusion no 39 also reproduces the mutual recognition principle requesting a "greater mutual recognition of each other courts" in order to achieve "effective judicial cooperation in the fight against cross border crime"; see Cardiff European Council, 15 and 16 June 1998, Presidency Conclusions, available at http://www.europarl.europa.eu/summits/car1_en.htm (last visited: 31 March 2017).

${ }^{51}$ Seen as the approximation of laws; see further ch. 3. Also M Jimeno Bulnes, Un proceso europeo para el siglo XXI (Madrid, Civitas \& Thomson Reuters, 2011) 35.

${ }^{52}$ See M Jimeno Bulnes, 'Perspectiva de la orden europea de detención y entrega: el principio de reconocimiento mutuo y la cooperación judicial en la Unión Europea', in J Burgos Ladrón de Guevara (ed), La cooperación judicial entre España e Italia (San Sebastián, Instituto Vasco de Derecho Procesal, 2017) 5. Also, for a comparative view between Common Law and Civil Law tradition applied to criminal procedure see M Jimeno-Bulnes, 'American criminal procedure in a European context' (2013) 21 Cardozo Journal of International and Comparative Law 409.
}

53 CJEU, Rewe Zentrale $A G$ v. Bundesmonopolverwaltung für Branntwein, No 120/78 (ECLI:EU:C:1979:42), Judgment (20 February 1979). See recently A Mattera, 'La reconnaissance mutuelle: une valeur historique ancienne, un principe juridique intégrationniste, l'assise politique d'un modèle de société humaniste: à l'occasion du 30e anniversaire de l'arrêt "Cassis de Dijon"” [2016] Revue du droit de l'Union Européenne 457.

${ }^{54}$ Expression from L Marafioti, 'Orizzonti investigativi europei, assistenza giudiziaria e mutuo riconoscimento', in T Bene (ed) L'ordine europeo d'indagine: criticità e prospettivi (Turin, Giapicchelli, 2016) 9 at 12. 
accordance with the previous Commission Decision 2014/858/EU of 1 December 2014. ${ }^{55}$ The most relevant one is, undoubtedly, Council Framework Decision 2002/584/JHA of 13 June 2002 on the European Arrest Warrant and the Surrender Procedures between Member States. ${ }^{56}$ It was transposed through the Extradition Act 2003 in the $\mathrm{UK}^{57}$ and through Law 3/2003, on March $14^{\text {th }}$, on the European Arrest Warrant and Surrender in Spain ${ }^{58}$ where it has now been replaced by the general law on mutual recognition in criminal matters. ${ }^{59}$ Both UK and Spain have been very active

\footnotetext{
${ }^{55}$ See supra note 21 and S Peers, 'Justice and Home Affairs Law since the Treaty of Lisbon: a fairy-tale ending?', above n 15 at 27. As example from a procedural view, besides the EAW: (12) Council FD 2005/214/JHA on the Application of the Principle of Mutual Recognition to Financial Penalties, OJ EU L 76 of 22 March 2005, 16; (13) Council FD 2006/783/JHA on the Application of the Principle of Mutual Recognition to Confiscation Orders, OJ EU L 328 of 24 November 2006, 59; (18) Council FD 2008/909/JHA on the Application of the Principle of Mutual Recognition to Judgments in Criminal Matters Imposing Custodial Sentences or Measures Involving Deprivation of Liberty for the Purpose of Their Enforcement in the European Union, OJ EU L 327 of 5 December 2008, 27; (25) FD 2009/829/JHA of 23 October 2009 on the Application between Member States of the European Union, of the Principle of Mutual Recognition to Decisions of Supervision Measures as an Alternative to Provisional Detention, OJ EU L 294 of 11 November 2009, 2. However, it is considered to be the EAW 'the single most important pre-Lisbon police and criminal justice measure' according to House of Lords EU Committee; see E. Baker, 'The United Kingdom and its Protocol 36 Opt-Out: is police judicial cooperation in criminal matters within the EU losing momentum', above $\mathrm{n} 20$ at 244.

${ }^{56}$ OJ EU L 190 of 18 July 2002, 1, amended by Council FD 2009/299/JHA Enhancing the Procedural Rights of Persons and Fostering the Application of the Principle of Mutual Recognition to Decisions Rendered in the Absence of the Persons Concerned at the Trial, OJ EU L 81 of 27 March 2009, 24. On the EAW see also Ambos and Bock, 'Brexit and the European Criminal Justice System - An Introduction', above $\mathrm{n} 48$ at 3.4.1.

${ }^{57}$ Enacted on 20 November 2003 and available at http://www.legislation.gov.uk/ukpga/2003/41/contents (last visited: 31 March 2017). For a comparative view between EAW implementation in UK and Spain at the time see M Jimeno-Bulnes, 'The enforcement of the European Arrest Warrant. A comparison between Spain and the UK' (2007) 15 European Journal of Crime, Criminal Law and Criminal Justice 263.

${ }^{58}$ BOE no $65,17.3 .2003,10244-10258$ available at https://www.boe.es/diario boe/txt.php?id=BOE-A2003-5451 (last visited: 31 March 2017). See M Jimeno Bulnes, 'La orden europea de detención y entrega: aspectos procesales' (2004) Diario la Ley, 19 March, no 5979, 1 and 'Orden de detención europea' in M. Jimeno Bulnes (ed.), La cooperación judicial civil y penal en el ámbito de la Unión Europea: instrumentos procesales, supra note 29, 299-348.

59 Art. 34-62 Law 23/2014, on 20 November, on mutual recognition of criminal resolutions in the European Union, BOE no 282, 21.11.2014, 95437-95993 available at https://www.boe.es/diario_boe/txt.php?id=BOE-A-2014-12029 (last visited: 31 March 2017). See also comments by $\mathrm{M}$ Jimeno Bulnes, 'La orden europea de detención y entrega: análisis normativo', in C Arangüena Fanego, M de Hoyos Sancho and C Rodriguez-Medel Nieto (eds) Reconocimiento mutuo de resoluciones penales en la unión Europea (Cizur Menor, Aranzadi, 2015) 35.
} 
Member States giving rise to a large corpus of national case-law, ${ }^{60}$ sometimes with ECJ intervention in response to requests for preliminary rulings, as in the Melloni case. ${ }^{61}$

In addition to the success of the EAW in general terms for all Member States according to official statistics, ${ }^{62}$ a further relevant judicial practice between the UK and Spain can be appreciated. Approximately 30/40 persons are annually surrendered by Spain to the UK within the framework of the EAW as recently reported by the British liaison magistrate. ${ }^{63}$ Bilateral cooperation between Spain and the UK works especially well in relation with both terrorism and drug-trafficking cases; while the former are especially related to Spain, the latter are more likely to relate to $\mathrm{UK}^{64}$

Concerning terrorism cases in Spain where an EAW is issued to the UK, judicial practice following the 11 March 2004 terrorist attacks in Madrid may be mentioned; ${ }^{65}$ here, some of the accused were handed over by the UK to be tried in Spain. In concrete, the British judicial authorities deported the suspect under the alias 'Botines' on 15 April 2006 to Spain, where he had been convicted on July 2003. The EAW issued by Spanish

\footnotetext{
${ }^{60}$ In Spain specifically see comments on national jurisprudence by M Jimeno Bulnes, 'The application of the European Arrest Warrant in the European Union. A general assessment', in C Fijnaut and J Ouwerkerk (eds), The future of police and judicial cooperation in the European Union (Leiden \& Boston, Martinus Nijhoff Publishers, 2010) 285 at 291; also extensively M Jimeno Bulnes, 'Régimen y experiencia práctica de la orden de detención europea', in M Jimeno Bulnes (ed) Justicia versus seguridad en el espacio judicial europeo (Valencia, Tirant lo Blanch, 2011) 109.

${ }^{61}$ CJEU, Melloni v Ministerio Fiscal, No. C-399/11 (ECLI:EU:C:2013:107), GC Judgment (26 February 2013), after the request by Spanish Constitutional Court (Tribunal Constitucional) available from the ECJ search page http://curia.europa.eu/jcms/jcms/j_6/en/ the case caused great debate at both a European and a national level. See criticism by A. Tinsley, 'Note on the reference in case C-388' (2012) 3 New Journal of European Criminal Law 19; also L Bachmaier Winter, 'Más reflexiones sobre la sentencia Melloni : primacía, diálogo y protección de los derechos fundamentales en juicios in absentia en el Derecho Europeo' [2015] Civitas. Revista española de derecho europeo 153.

${ }^{62}$ See information available at https://e-justice.europa.eu/content_european_arrest_warrant-90-en.do (last visited: 31 March 2017), although not all Member States have provided data. Appropriate table indicates along 2014: 14.700 issued EAWs, 9.660 traced and/or arrested persons and 5.480 surrendered persons.

${ }^{63}$ Mr. Benedict Leonard, 'Las consecuencias del Brexit. Cooperación con el Reino Unido', Reunión anual ReDPE 'Los retos del espacio Libertad, Seguridad y Justicia UE en el año 2016' (Madrid, 16 December 2016). I am grateful to my colleague Regina Garcimartín-Montero, who helped preparing a summary of his speech.

${ }^{64}$ Between 1978 and 1985 there were no agreements on extradition in place between Spain and England, although British criminals continue to evade justice in southern Spain. See for example both judgments by National Court, no 3/2014 of 28 March (JUR 2014/121514) and no 26/2014 of 27 October (JUR 2014/267054) available from the Spanish case-law database http://www.aranzadidigital.es Both are related to the conviction of several suspects, some born in the UK, who had also committed drugtrafficking offenses in the UK; it is stated in the 'police statement' (atestado) reports that the UK intended to issue an EAW after agreement between a prosecutor from the UK Crown Prosecution Service (CPS), who had travelled to Cadiz, and the Spanish anti-drug prosecutor in Cadiz.

${ }^{65}$ Other cases related to terrorism involving Spain and the UK have been presented by T Konstantinides, 'The Europeanization of extradition: how many light years away to mutual confidence' in C. Eckes and T. Konstantinides (eds), Crime within the Area of Freedom, Security and Justice. A European Public Prosecutor (Cambridge, Cambridge University Press, 2011) 192 at 201.
} 
Central Judge of the Investigative was issued on 12 August 2004, but there were requests from the $\mathrm{UK}$ for additional information relating to the facts and the dates on which the crimes were committed; hence the delay in the enforcment of the EAW. ${ }^{66}$ Despite his acquittal, due to the application of the exclusionary rule (prueba ilicita) in relation to telephone tapping authorised by the courts in Spain, the execution of the EAW was essential in order to ensure the presence of the accused at the trial, which would not otherwise have been held under Spanish procedural rules. ${ }^{67}$

Although bilateral cooperation between the UK and Spain on EAW generally functions quite well (especially, as said, in relation to matters of terrorism), ${ }^{68}$ there are however cases in which an EAW issued by Spanish judge or $\operatorname{court}^{69}$ is not enforced by the British judicial authorities. In these cases, the only solution it is to employ the traditional instruments of mutual assistance such as, the delivery of an international arrest warrant; hence, the warrant issued on 13 August 2015 by the Central Judge of the Investigative no $5,{ }^{70}$ in which a 'letter rogatory' requested international judicial assistance, following the failure of an earlier EAW issued by same Central Judge of the Investigative on 17 November 2014. The EAW in question had in fact been upheld in the first instance by a

66 See information provided by National Court judgment no 56/2007 on 28 September (JUR 2008/261227) available from http://www.aranzadidigital.es (restricted access). All of the accused persons were acquitted in the judgment that declared the nullity of the evidence presented at the trial, based on telephone tapping authorized by the courts without sufficient evidence of criminal activity.

${ }^{67}$ Art. 786 (1) Spanish Act on Criminal Procedure (Ley de Enjuiciamiento Criminal, henceforth LECrim) available at https://www.boe.es/buscar/act.php?id=BOE-A-1882-6036 (last visited: 31 March 2017); an English version may be purchased from the Spanish Ministry of Justice website http://www.mjusticia.gob.es/cs/Satellite/Portal/es/servicios-ciudadano/documentacion-publicaciones/ publicaciones/traducciones-derecho-espanol (last visited: 31 March 2017); note that it is the original act promulgated in 1882 after further amendments and not the new one enacted in 2016, despite the information provided by the Spanish Ministry of Justice. The provision expressly states that 'attendance by the accused and the defence lawyer is compulsory at the oral trial'; the only possible exception to this rule takes place when 'where the requested punishment does not exceed two years imprisonment or, if of a different type, where it does not last more than six years'.

${ }^{68}$ See, for example, a recent judgment of the National Court no 8/2016, on 6 May (ARP 2016/632, available at http://www.aranzadidigital.es); here the accused was surrendered by the UK on 20 July 2012 in execution of an EAW issued by the Central Judge of the Investigative on 10 February 2004 and convicted of perpetrating several crimes of terrorism.

${ }^{69}$ According to previous and new Spanish Law in implementation of the EAW, only judges and courts can issue an EAW in Spain; see Art. 35 (1) Law 23/2014, on 20 November, on mutual recognition of criminal resolutions in the European Union, BOE no 282, 21.11.2014, 95437-95993. See also comments by $M$. Jimeno Bulnes, by $M$ Jimeno Bulnes, 'La orden europea de detención y entrega: análisis normativo', above n 60 at 42 .

${ }^{70}$ ARP 2015/827 available at http://www.aranzadidigital.es 
Senior District Judge, but had then been revoked on appeal before the High Court of Justice (Queen's Bench Division). ${ }^{71}$

The likely solution after Brexit, if it is the case that EAW proceedings between UK and Member States cease, could be to resort to bilateral agreements, in order to establish fast-track surrender treaties. Previous bilateral fast-track surrender treaties might be recalled, enacted before the adoption of EAW, such as those between Italy and Spain ${ }^{72}$ and between Spain and the UK among others; the most recent one is the bilateral treaty signed in Madrid on 23 November 2001. These treaties could once again be employed, as any return to the obsolete mechanisms of extradition would not make any sense. ${ }^{73}$

\section{THE APPROXIMATION OF LEGISLATIVE INSTRUMENTS: PROCEDURAL RIGHTS}

The UK has been less encouraging in relation to the adoption of measures on the protection of the fundamental rights of individuals and their procedural rights. ${ }^{74}$ To some extent, the UK considers that 'human rights law emanating from Europe', or EU judicial cooperation in criminal matters, 'hinders extradition', ${ }^{75}$ which is obviously not the case as long as both areas are 'inherently' connected. ${ }^{76}$ In this context, since the adoption of the Treaty of Lisbon, the EU has gradually increased the protection of individual rights; ${ }^{77}$ the best example being the adoption of the so-called Roadmap for

\footnotetext{
${ }^{71}$ Case CO/1724/2015 \& CO/1815/2015, judgment by the Administrative Court of this section on 31 July 2015 against the judgment of a Senior District Judge (Westminster Magistrates Court) on 14 April 2015 upholding the appeal brought by the accused, alias Antxon, a member of ETA Basque terrorist group. He was accused of various crimes related to terrorism such as belonging to a terrorist organization and false employment of public documents.

${ }^{72}$ Protocol on the pursuit of serious crime by superseding extradition within a common area of justice, signed in Rome on 28 November 2000. See comment by B Reverón Palenzuela, 'Notas sobre el tratado suscrito entre España e Italia para la persecución de delitos graves de 28 de noviembre de 2000. Especial referencia a la extradición de condenados en rebeldía' [2001] Anales de la Facultad de Derecho 401.

${ }^{73}$ On this opinion, eg, J Dedeyne-Amann, 'L'extradition: un anachronisme au sein de l'Union européenne', in G de Kerchove and A Weyembergh (eds.) La reconnaissance mutuelle des decisions judiciaires pénales dans l'Union européen/ Mutual recognition of judicial decisions in the penal field within the European Union (Bruxelles, Editions de l’Université Libre de Bruxelles, 2001) 177.

${ }^{74}$ See Mitsilegas, 'The uneasy relationship between the UK and European Criminal Law: from opt-outs to Brexit?' supra note 10 at 519 .

${ }^{75}$ P Arnell, 'The European Human Rights influence upon UK extradition - Myth debunked' (2013) 21 European Journal of Crime, Criminal Law and Criminal Justice 317 at 317.

${ }^{76}$ See specifically H Raulus, 'Fundamental rights in the area of freedom, security and justice', in S Wolff, F A N J Goudappel and J de Zwaan (eds) Freedom, security and justice after Lisbon and Stockholm (The Hague, T.M.C. Asser Press, 2011) 21-240.

77 See Ouwerkerk, 'Criminal justice beyond national sovereignty. An alternative perspective of the Europeanization of Criminal Law', above n 23 at 28.
} 
strengthening procedural rights of suspects or accused persons in criminal proceedings ${ }^{78}$ in 2009 providing minimum rules in this area.

In fact, the UK agreed to the first measures adopted in 2010 and 2012 in the field of interpretation and translation and in relation to the right to information in criminal proceedings. ${ }^{79}$ In contrast, the UK has shown little inclination to participate in any further regulation on procedural rights, since the enactment of Directive 2013/48/EU of 22 October 2013 on the Right of Access to a Lawyer in Criminal Proceedings. ${ }^{80}$ Its decision is borne out by its voting record on this initiative in the Council of the EU, ${ }^{81}$ as well as those related to further regulation on the presumption of innocence, procedural safeguards for children, and legal aid. ${ }^{82}$

\footnotetext{
${ }^{78}$ Resolution of the Council of 30 November 2009, OJ EU C 295 of 4 December 2009, 1. See specifically M Jimeno-Bulnes, 'The EU Roadmap for strengthening procedural rights of suspected or accused persons in criminal proceedings (2009) 2 Eucrim, 157; see also Centre for European Policy Studies, Towards common standards on rights of suspected and accused persons in criminal proceedings in the EU? (Brussels:, 2010) available at https://www.ceps.eu/publications/towards-common-standards-rightssuspected-and-accused-persons-criminal-proceedings-eu (last visited: 31 March 2017).

${ }^{79}$ Directive 2010/64/EU of the European Parliament and of the Council on the Right to Interpretation and Translation in Criminal Proceedings, OJ EU L 280 of 26 October 2010, 1, and Directive 2012/13/EU of the European Parliament and of the Council on the Right to Information in Criminal Proceedings, OJ EU L 142 of 1 June 2012, 1, both of them implemented in Spain under the Organic Law 5/2015, on 27 April 2015, amending especially Arts. 118 and 520 LECrim, BOE no 101, 28.4.2015, 36559-36568 available at official website https://www.boe.es/ See comments on the Spanish transposition of these directives by C Arangüena Fanego, 'Nuevos avances en la harmonización de garantías procesales en la Unión Europea', in M I González Cano (ed), Cooperación judicial penal en la Unión Europea. Reflexiones sobre algunos aspectos de la investigación y el enjuiciamiento en el espacio europeo de justicia penal (Valencia, Tirant lo Blanch, 2016) 267.

${ }^{80}$ OJ EU L 294 of 6 November 2013, 1, implemented in Spain under Organic Law 13/2015, on 5 October, amending again Arts. 118 and 520 LECrim. See comments on European regulation by M Jimeno Bulnes, 'La Directiva 2013/48/UE del Parlamento Europeo y del Consejo de 22 de octubre de 2013 sobre los derechos de asistencia letrada y comunicación en el proceso penal: ¿realidad al fin?' (2014) 18 Revista de Derecho Comunitario Europeo 443; also L Bachmaier Winter, 'The EU Directive on the right to access to a lawyer: a critical assessment', in S Ruggeri (ed), Human Rights in European Criminal Law. New developments in European legislation and case-law after the Lisbon Treaty (Heidelberg, Springer International, 2015) 111. On Spanish legal practice see also a brief comment by M Jimeno Bulnes, 'La nueva configuración del derecho de asistencia letrada en la Unión Europea', in I Díaz-Picazo Giménez and J. Vegas Torres (eds), Derecho, justicia, universidad. Liber Amicorum a Andrés de la Oliva Santos, t.II, (Madrid, Editorial universitaria Ramón Areces, 2016) 1855 at 1878.

${ }^{81}$ See voting result, document no 14515/13, 7 October 2013, VOTE 59, INF 162, PUBLIC 168, available through the search form of the European Council website http://www.consilium.europa.eu/register/ as well as other voting records on previous directives on procedural rights in criminal proceedings.

${ }^{82}$ Directive 2016/343/EU of the European Parliament and of the Council on the Strengthening of Certain Aspects of the Presumption of Innocence and of the Right to be Present at the Trial in Criminal Proceedings, OJ EU L 65 of 11 March 2016, 1; Directive 2016/800/EU of the European Parliament and of the Council on Procedural Safeguards for Children who are Suspects or Accused Persons in Criminal Proceedings, OJ EU L 132 of 25 May 2016, 1; Directive 2016/1919/EU of the European Parliament and of the Council on Legal Aid for Suspects and Accused Persons in Criminal Proceedings and for Requested Persons in European Arrest Warrant Proceedings, OJ EU L 297 of 4 November 2016, 1. For a general review of these new directives see different papers under common title 'Focus: procedural rights and cooperation - New tendencies' (2016) 10 (1) Eucrim.
} 
The thorniest issue in the previous Proposal for a Council FD on Certain Procedural Rights in Criminal Proceedings throughout the EU launched by the European Commission in 2004 was precisely the right to legal counsel. ${ }^{83}$ This right is contemplated throughout police questioning according to the Salduz doctrine, ${ }^{84}$ which up until now was not provided for in all national legislations in the Member States. ${ }^{85}$ In the UK, some exceptions are also expressly contemplated in relation to serious offences such as terrorism according to Art. 56 PACE, ${ }^{86}$ which has been accepted by the European Court of Human Rights ("ECtHR"). ${ }^{87}$ Hence, its alignment with the group of countries (Czech Republic, Ireland, Malta and Slovakia) that at the time defended the sufficiency of Ars. 5 and 6 ECHR for the protection of the procedural rights of suspects and/or accused persons in criminal proceedings. ${ }^{88}$ However, numerous examples of case-law pronounced in Strasbourg have censured EU Member States (including the UK and Spain) for the violation of procedural rights. ${ }^{89}$

Spain also has its own experiences of failing to comply with the procedural rights recognized in the new directives. Not surprisingly, it has also experienced important issues in relation to the enforcement of certain procedural rights of suspected persons

\footnotetext{
${ }^{83}$ On 28 April 2004, COM(2004) 328 final. See comments by M Jimeno-Bulnes, 'The Proposal for a Council Framework Decision on certain procedural rights in criminal proceedings throughout the European Union', in E Guild and F Geyer (eds), Security versus Justice? Police and judicial cooperation in the European Union (Aldershot and Burlington, Ashgate, 2008) 171.

${ }^{84}$ ECtHR, Salduz v. Turkey, Application no. 36391/02, Judgment (27 November 2008); also more recently, for example, ECtHR, Yilmaz Demir v. Turkey, Application no. 44767/06, Judgment (15 October (2013) and Navone and others v. Monaco, Application nos. 62880/11, 62892/11 and 62899/11, Judgment (24 October 2013).

${ }^{85}$ For a comparative review, see E Cape, J Hodgson, T Prakken and T Spronken (eds), Suspects in Europe: procedural rights at the investigative stage of the criminal process in the European Union (Antwerpen and Oxford, Intersentia, 2007) 19-20 in relation with the exception to legal advice during police cross-examination.

86 Police and Criminal Evidence Act 1984, available at http://www.legislation.gov.uk/ukpga/1984/60/contents (last visited: 16 February 2017). Similar information is also available online from the British government at https://www.gov.uk/arrested-yourrights/legal-advice-at-the-police-station (last visited: 31 March 2017).

${ }^{87}$ See for example the case of Ibrahim and others v. the United Kingdom (2014) ECHR 1392, judgement on 16 December 2014 rejecting a possible violation of Art. 6 (3) (c) ECHR; the detainees were accused of committing the London bombings in July 2005 in which 52 people lost their lives.

${ }^{88}$ According to document no 11788/06, 4 September 2006, DROIPEN 49, available at the EU Council website http://www.consilium.europa.eu/register/en/, questioning the relationship between the EU Proposal on procedural rights and the CHR, suggesting that the Council of Europe be consulted on the matter.

${ }^{89}$ In relation to the UK, see for example Arnell, 'The European Human Rights influence upon UK extradition - Myth debunked', above n 75. Also, in relation with ECtHR tasks see generally M Egan, 'Non-conviction based sanctions: the Court of Justice v. the European Court of Human Rights, who decides?' (2011) 19 European Journal of Crime, Criminal Law and Criminal Justice 167.
} 
held in police detention, ${ }^{90}$ because there is no clear provision, for example, on the right to private consultation between counsel and client before police questioning, guaranteed in Art. 3 (3) (a) Directive 2013/48/EU, even though the right to legal assistance is guaranteed in Arts. 118 and 520 of the Spanish Act on Criminal Procedure (Ley de Enjuiciamiento Criminal or LECrim). ${ }^{91}$ Spanish lawyers have another 'axe to grind' in relation to detention in police headquarters, which is access to police reports (atestado) and interviews of suspects held in detention. The direct effect of Art. 7 of Directive 2012/13/EU of the European Parliament and of the Council of 22 May 2012 on the Right to Information in Criminal Proceedings ${ }^{92}$ ensures access to such reports, repeatedly demanded by the Spanish Bar Associations. A very recent constitutional judgement from the Spanish Constitutional Court of 30 January $2017^{93}$ has upheld that direct effect in response to an appeal for relief (amparo) from a Spanish citizen, whose lawyer was denied access to a police report on his questioning; the citizen in question was arrested on 11 June 2014, some days after the deadline of 2 June 2014 set for the transposition of the Directive according to its Art. 11 (1).

\section{CONCLUDING REMARKS}

At the time of writing Theresa May has triggered Art. 50 TEU by way of a formal letter handed in person to Council President Donald Tusk. ${ }^{94}$ The proceedings in the British

90 See R Rivero Ortiz, 'Asistencia letrada al letrado y la normativa comunitaria. El anhelado fin del abogado convidado de piedra y del tancredismo profesional' [2015] Diario La Ley, 31 March, no 8511, $\mathrm{http}$ //diariolaley.laley.net. See also generally in relation to new European procedural regulation Klip, European Criminal Law. An integrative approach. above n 22 at 260 et ff; in relation to Spanish criminal procedure specifically see at the time L Bachmaier Winter and A del Moral García, Criminal Law in Spain, (2 ed., The Hague, Wolters Kluwer, 2012) 205.

91 Carefully worded as 'the right to meet in private and communicate with the lawyer'; such communication can take place, for example, by telephone. See P García Molina, 'La transposición de la Directiva 2013/48/UE en lo que respecta al derecho a la asistencia de letrado en los procesos penales a la luz del Anteproyecto de Ley Orgánica de modificación de Ley de Enjuiciamiento Criminal' [2015] Revista General de Derecho Europeo, 9.

92 See above $\mathrm{n} 80$. See comments by V Faggiani, 'El derecho a la información en los procesos penales en la UE: la Directiva 2012/13/UE, de 22 de mayo de 2012' (2013) (30) Revista General de Derecho Procesal, http://www.iustel.com; also from the practitioners' view F J Saénz de Pipaón y del Rosal, 'Asistencia al detenido y ... ¿derecho de información?' (2015) Diario La Ley, 31 March, no 8511, http://diariolaley.laley.net

${ }^{93}$ Defence appeal no 7301/2014. I am grateful to my colleagues Nicolás Cabezudo and Camino Vidal, as this judgement is not yet available through the search form of the Spanish Constitutional Court website http://hj.tribunalconstitucional.es/es

${ }^{94}$ Full text of Theresa May's letter to EU Council is available at http://www.bbc.com/news/uk-politics39431070 (last visited: 2 April 2017). The British press has reported it as the breakdown of a decades long-marriage' comparing with a divorce; see for example https://www.theguardian.com/politics/2017/mar/29/britain-and-eu-the-breakdown-of-a-decades-longmarriage (last visited: 31 March 2017). In Spain see JA Yturriaga Barberán, 'Divorcio a la inglesa: el comienzo del fin del Brexit' [2017] Diario La Ley, 30 March, no 8952, http://diariolaley.laley.net 
Parliament to invoke Art. 50 TFEU for the withdrawal of the UK from the EU are fully underway. ${ }^{95}$ Significant concern has already been raised about the consequences of Brexit in different areas and not only in European Criminal Law. This is the case, for example, of EU citizens living in UK, ${ }^{96}$ to whom a sort of permanent residency has been unsuccessfully proposed; ${ }^{97}$ and vice-versa, for the millions of UK nationals residing in EU countries, especially in the south of Europe, and particularly in southern Spain. ${ }^{98}$

There are grave concerns in the UK over two main topics in relation to European Criminal Law policy according to two reports prepared by the UK Parliament of December 2016. One is the UK-UE security goal to be achieved through police and judicial cooperation in criminal matters with the maintenance of British participation in EU agencies, if possible, and the provision of alternatives to mutual recognition instruments. ${ }^{99}$ In the case of participation in agencies, the UK is especially interested in maintaining cooperation with Europol and Eurojust; in relation to the latter, it is examining the roles of Norwegian, Swiss and American liaison magistrates posted by their respective countries that are not EU members as mentioned earlier. ${ }^{100}$

In the case of mutual recognition instruments, the main objective is certainly to maintain an instrument as close as possible to the EAW, which, as stated, 'is a critical component of the UK's law enforcement capabilities'. ${ }^{101}$ After exploring other options, ${ }^{102}$ it looks as though the best alternative will be to substitute the EAW by the

\footnotetext{
95 European Union (Notification of Withdrawal) Bill 2016-17 available at http://services.parliament.uk/bills/2016-17/europeanunionnotificationofwithdrawal.html (last visited: 31 March 2017).

${ }^{96}$ A total of 131.335 Spaniards are registered at Spanish Consulates in the UK (110.838 in the Consulate General of Lodon and 20.497 in the Edinburgh Consulate) according to the latest data from the Ministry of Foreign Affairs. However, the real number is likely to be higher, as it is common for people not to register at the Consulate, even if they live permanently outside of Spain. Recently, the Spanish Embassy in London has established a specific service to resolve doubts of its citizens residing in the UK or who wish to move there to work or study; see information provided in (2017) Diario La Ley, March 30, num. 8953, http://diariolaley.laley.net

97 See inf ormation provided, eg, at https:/www.theguardian.com/politics/2017/feb/08/mps-reject-brexitbill-amendment-to-protect-eu-citizens-in-uk (last visited: 31 March 2017).

98 See M Corera Izu, "Brexit: la gran oportunidad. "Nuestros británicos"" (2017) Diario La Ley, 3 February, no 8914, http://diariolaley.laley.net.

99 See House of Lords, European Union Committee, 'Brexit: future UK-EU security and police cooperation', $7^{\text {th }} \quad$ Report, Session 2016-17, HL paper 77 available at https://www.parliament.uk/documents/lords-committees/eu-home-affairs-subcommittee/Evidence-BrexitPolicing.pdf (last visited: 31 March 2017).

${ }^{100}$ See ibid at 23-24.

${ }^{101}$ See ibid at 38 .

${ }^{102}$ In particular, 1957 Council of Europe Convention on Extradition; see HL Report, 'Brexit: future UKEU security and police cooperation', above n 98 at 38.
} 
provision of bilateral extradition agreements similar to those that exist between both Norway and Iceland and the EU. ${ }^{103}$ There is also the possibility of signing 'fast-track surrender' bilateral treaties, similar to those that previously existed between UK and Spain, in 2001, before the EAW. Nevertheless, there are doubts over the efficiency of each solution with regard to the grounds for refusal that may be added (e.g., nationality).

In contrast, the future of the second topic is much more uncertain, as it is the protection of fundamental (and procedural) rights. As previously mentioned, there is great controversy over the residence rights of EU nationals currently in the UK and UK nationals in $\mathrm{EU}^{104}$ and major concerns over any sort of fundamental rights guaranteed under EU Law. The fear is recognized that the new government will reduce some of the fundamental rights (although it is unclear which ones) acquired under EU Law; ${ }^{105}$ besides, the guidance according to new directives on procedural rights and CJEU case law will be missed. All in all, it has been argued that the so-called Great Repeal Bill should maintain 'any fundamental rights, which UK citizens currently possess under EU Law'.

Finally, it is worthwhile noting the temporal coincidence of the Brexit process with the celebration of the $60^{\text {th }}$ anniversary of the Treaty of Rome on March $27^{\text {th }} \cdot{ }^{106}$ The UK may be reconsidering the risks of leaving the $\mathrm{EU}$ or at least reviewing the real consequences of the imminent negotiations and what may in reality be achieved. Whatever the future holds for the EU, with or without the UK, can be summarized in President Donald Tusk's letter to the 27 heads of remaining Member States before the

\footnotetext{
${ }^{103}$ Council Decision 2014/835/EU on the Conclusion of the Agreement between the European Union and the Republic of Iceland and the Kingdom of Norway on the surrender procedure between the Member States of the European Union and Iceland and Norway, OJ EU L 343 of 28 November 2014, 1.

${ }^{104}$ House of Commons \& House of Lords, Joint Committee on Human Rights, 'The human rights implications of Brexit', 5th Report, Session 2016-17, HL paper 88 \& HC 695, available at https://www.parliament.uk/business/committees/committees-a-z/joint-select/human-rightscommittee/inquiries/parliament-2015/human-rights-brexit-16-17/ (last visited: 31 March 2017) 4. As stated, 'it is not appropriated to treat individual's fundamental rights as a bargaining chip in negotiations with the remaining EU Member States'.

${ }^{105}$ Textually, 'EU Law currently underpins a great many fundamental rights and yet it is unclear whether the Government intends to remove any rights which UK citizens possess under EU Law (and, if so, which rights are under threat)'; see ibid at 6 .

${ }^{106}$ See general information https://europa.eu/european-union/eu60_en (last visited: 31 March 2017). See for Spain J C Fernández Rozas, 'El 60 aniversario de los Tratados de Roma: algo más que una simple celebración', (2017) Diario La Ley, 31 March, no 8511, http://diariolaley.laley.net
} 
Malta summit last February $3^{\text {rd }}$, 2017: 'United we stand, divided we fall'; ${ }^{107}$ equally applicable to European Criminal Law.

107 Available at http://www.consilium.europa.eu/en/press/press-releases/2017/01/31-tusk-letter-futureeurope/ (last visited: 31 March 2017)- 